\title{
Graphical-analytic model to form investment policy of industrial enterprise
}

\author{
V.G. Pluzhnikov ${ }^{1, *}$, S.I. Kukharenko ${ }^{1}$, and S.A. Shikina ${ }^{1}$ \\ ${ }^{1}$ South Ural State University, Chelyabinsk, Russia
}

\begin{abstract}
The article is devoted to the research of graphical-analytic method to form investment policy of industrial enterprise in the capacity of a specific tool to achieve the strategic aim at various stages of lifecycle (LCS). The necessary to formalize the system of estimations is caused by lack of methodological basis of defining quantitative characteristics relying on qualified criteria. To designing graphical-analytic pattern in the capacity of a tool forming investment policy of organisation within the stated development strategy. The comparative analysis of factors that are influencing the investment policy and the stage of organisation life-cycle has been carried out. Theoretical-methodological basis concepts of the development have been considered. All criteria for quantitative estimation of the stage of organisation life-cycle and the performance of investment policy have been proved in the course of the research. The classific characteristics of criteria to estimate the stage of the life-cycle and concepts of investment policy have been formalized. The choice of criteria and interval boundary and its characteristics has been made. The estimation method of the stage of the organisation life-cycle has been introduced. The research, that has been carried out, proves the possibility to develop practical application of graphical-analytic pattern forming investment policy and estimating the stage of life-cycle and type of the investment policy of an analyzed organisation.
\end{abstract}

\section{Introduction}

Forming effective investment policy in the frame of the stated development strategy of an organisation is a crucial element involved into the process of strategic management. The concepts of the policy are defined due to subjective and objective factors which influence the functioning and development of an undertaking. One of these factors is the realization of the development strategy of the undertaking should correspond to its stage of the life-cycle (LCS). The scholarly interest in problems of the organisation development at various stages of its life-cycle has increased for the last years (Shirokova 2007). The factors are tightly connected with the fact that each economic system is dependent on subjective assumptions to take some administrative measures. One of the lines of the research is to make an accurate choise of the stated development strategy in the frame of the investment policy. Therefore, a crucial issue of forming the investment policy is to account and control dynamic characteristics of the external environment and investment possibilities of the undertaking to correct its investment policy according to the stated development strategy.

The notion of the investment policy is debatable in scholarly literature. The main definitions of the investment policy. Table 1 .
Table 1. Characteristics of the investment policy.

\begin{tabular}{|c|c|}
\hline Authors & The concept of the notion \\
\hline Blank I.A. & $\begin{array}{c}\text { A component of the general financial } \\
\text { strategy that consists in choosing and } \\
\text { realization of the most effective } \\
\text { financial investments aimed at high rates } \\
\text { of the development and permanent } \\
\text { growth of the marketing cost of a } \\
\text { company. }\end{array}$ \\
\hline $\begin{array}{c}\text { Yendovitsky } \\
\text { D.A }\end{array}$ & $\begin{array}{c}\text { Factual realization of investment policy } \\
\text { (Yendovitsky, 1998) }\end{array}$ \\
\hline $\begin{array}{c}\text { A system of arrangements providing a } \\
\text { M.V. }\end{array}$ & $\begin{array}{c}\text { beneficial investment and quick payback } \\
\text { period to guarantee the financial } \\
\text { stability, financial solvency, increased } \\
\text { competitive ability and providing } \\
\text { conditions for the future development } \\
\text { (Charayeva, 2010). }\end{array}$ \\
\hline
\end{tabular}

In the frame of the study the investment policy is considered to be a system of arrangements (business processes) providing a beneficial investment and quick payback period aimed at the realization of strategic objectives for the organisation development. Ultimately, the organisation development, standing on a particular type of the development strategy, may involve the following types of the investment policy. Table 2 (Blank, 2012). 
Table 2. The main types of the investment policy.

\begin{tabular}{|c|c|}
\hline The type & The concept of the notion \\
\hline Concervative & $\begin{array}{c}\text { aimed at minimization of the } \\
\text { investment risk as a priority } \\
\text { objective }\end{array}$ \\
\hline Moderate & $\begin{array}{c}\text { aimed at choosing investment } \\
\text { objects which obtain mid- } \\
\text { market level of the current } \\
\text { profitability, rates of capital } \\
\text { expansion and risk level. }\end{array}$ \\
\hline Aggressive & $\begin{array}{c}\text { aimed at maximization of the } \\
\text { current profit from the } \\
\text { investing of capital the } \\
\text { nearest period }\end{array}$ \\
\hline
\end{tabular}

The type of the investment policy is defined by the Coefficient of investment activity (Cia).

\section{The impact of the development strategy on the investment policy}

According to the theory and practice of organisation management there are basic classifications and ways of the investment policy which correspond to a particular type of strategies. The main types and ways of strategies of the investment policy. They present in table 3 .

In spite of the traditional point of view new classific characteristics are included in the table: strategies of traditional and specific development. This classification criterion is defined by the correlation of the type of investment policy and the life-cycle stage (LCS):

- strategies of "natural development" are considered as realization of eventual strategic changes in the organisation development using standard strategies and ways of investment policy in accordance with the life-cycle stage (LCS) of the undertaking (Table 3);

- strategies of "specific development" reflect the formation of the business renovation. This process is based on the usage of strategies aimed at diversification of business activities (Table 3).

Thus investment policy is a tool for accomplishing strategic objectives at various life-cycle stages (LCS) of undertaking development. It's characterized by different intensity of the investment policy.

Table 3. The main strategies and ways of the investment policy of natural development at different stages of the life-cycle.

\begin{tabular}{|c|c|c|}
\hline Stages & Types of strategies & Ways of the investment policy \\
\hline \multicolumn{3}{|r|}{ Strategies of the "natural development" } \\
\hline Birth & $\begin{array}{l}\text { The strategy aimed at } \\
\text { the exploration of } \\
\text { new business types }\end{array}$ & $\begin{array}{l}\text { assimilation, formation new business types, new types of products, technology, } \\
\text { materials and new markets; } \\
\text { development of new manufacture; } \\
\text { recruitment of investors for development of venture business and etc. }\end{array}$ \\
\hline Growth & $\begin{array}{l}\text { Concentrated growth } \\
\text { strategy } \\
\text { and/or } \\
\text { integrative growth } \\
\text { strategy }\end{array}$ & $\begin{array}{c}\text { increase production volumes; } \\
\text { capital-raising for acquisition of high-technology equipment and expansion of the } \\
\text { circulating capital; } \\
\text { Improve results of activity by means of application of new technological systems or } \\
\text { new technology; } \\
\text { Development of economy management subject by means of expansion with the help of } \\
\text { integrative processes within the industrial chain (amalgamation, takeover, } \\
\text { consolidation) } \\
\text { increase fixed assets based on the engaging of long-term financial sources; } \\
\text { optimization of financial sources by means of bringing long-term liabilities, } \\
\text { strengthening of financial stability, increase of creditworthiness and investment } \\
\text { attraction of an economic entity; }\end{array}$ \\
\hline Stabilization & $\begin{array}{l}\text { Strategy of } \\
\text { economizing costs } \\
\text { or } \\
\text { integrative growth } \\
\text { strategy } \\
\end{array}$ & $\begin{array}{c}\text { preservation of competitive position at the market; } \\
\text { providing effective usage of resource organisation possibilities; } \\
\text { insurance and acquisition of pertinent guarantees against non-commercial risks and etc. } \\
\text { development of the economic entity by means of expansion of integrative processes } \\
\text { within industrial chain (amalgamation, takeover, consolidation); }\end{array}$ \\
\hline Stagna-tion & $\begin{array}{c}\text { Strategy of } \\
\text { economizing costs }\end{array}$ & $\begin{array}{c}\text { reduction and restructuring of assets; } \\
\text { providing effective usage of resource organisation possibilities; } \\
\text { warning of bankruptcy based on winding up of unprofitable enterprises, downsizing, } \\
\text { selling a part of the assets and etc. }\end{array}$ \\
\hline \multicolumn{3}{|r|}{ Strategies of "specific development" } \\
\hline Stabilization & $\begin{array}{c}\text { Strategy of } \\
\text { diversification }\end{array}$ & $\begin{array}{l}\text { assimilation, formation of new business types, new types of productes, technology, } \\
\text { materials and new markets. } \\
\text { development of new manufacture; } \\
\text { bringing of long-term capital } \\
\text { repurposing, reconstruction, modernization and renovation of separate types of } \\
\text { equipment; } \\
\text { modernization and implementation of new equipment; }\end{array}$ \\
\hline Stagnation & $\begin{array}{c}\text { Strategy of } \\
\text { diversification }\end{array}$ & $\begin{array}{c}\text { anti-recessionary policy aimed at financial stabilization of the undertaking in the } \\
\text { process of crisis recovery; } \\
\text { warning of bankruptcy based on winding up of unprofitable enterprises, selling a part } \\
\text { of the assets and etc. }\end{array}$ \\
\hline
\end{tabular}




\section{Impact of the life-cycle stage (LCS) on the business investment policy}

There is no a traditional method of the LCS impact on business characteristics in the economic science (Ivashkovskaya and Yangel, 2007). In different surveys (Shirokova, 2007; Kushelevich, 2004; Morgunov, 2006; Glazl, 2000) researchers mention several models/patterns describing organisation development and LCS.

Of special importance can be mentioned: theoretical and empirical models of the LCS organisation of the following authors: Greiner, 2002; Miller, 1984; Lester et al., 2003; Ivashkovskaya, 2007; Shirokova, 2006 and etc. (Lester et al., 2003), (Ivashkovskaya, 2007), (Shirokova, 2006) and etc. The authors argue that the life-cycle is targeting that is made by means of analyzing economic and financial characteristics. However, there is no general understanding of the organisation transition from one stage to another and quantitative estimate methods of qualitative LCS characteristics (Shirokova and Serov, 2006). Although the researchers agree upon the fact that each LCS stage obtains a set of unique qualitative characteristics; sequence of LCS stages; and every stage is a result of the previous one; models have a broad range of organisational contextual characteristics (Shirokova, 2006).

In this work the Greiner's model has been adapted (Greiner, 2002) due to the result of empirical research devoted to the number of stages, choosing of LCS characteristics and transition mechanism from one stage to another. The 5-phased model is included in the LCS theory and constitutes 5 stages of organisation development: birth, growth, stabilization, stagnation and decay (bankruptcy). In this work only the first four stages are considered: birth, growth, stabilization and stagnation. The decay stage is out of the list because the organisation management is subject to specific legal norms (Federal Law, NO 127 - FZ 17.09.09 On Insolvency (Bankruptcy)). So that the 5-point estimate scale of LCS within the description of each point is used. Table 4. (Pluzhnikov and Shikina, 2015).

Table 4. Estimate scale LCS.

\begin{tabular}{|c|c|c|}
\hline \begin{tabular}{|c|} 
No. Name \\
of the \\
stage
\end{tabular} & Scale meaning & Note \\
\hline 1 Birth & from 0 to 1 & $\begin{array}{c}\text { The company age is less than } \\
10 \text { years, has informal } \\
\text { structure, owner is a head of } \\
\text { management. } \\
\text { Characteristic meaning can be } \\
\text { negative }\end{array}$ \\
\hline 2 Growth & from 1 to 2 & $\begin{array}{l}\text { Growth: formalization of } \\
\text { management solutions, } \\
\text { economic indicators, } \\
\text { formalization of organisational } \\
\text { structure and investment policy }\end{array}$ \\
\hline \begin{tabular}{|c|}
3 \\
Stabilizatio \\
$\mathrm{n}$ \\
\end{tabular} & from 2 to 3 & $\begin{array}{c}\text { Sales gain reduces, } \\
\text { deterioration of economic } \\
\text { indicators, bureaucratization of }\end{array}$ \\
\hline
\end{tabular}

\begin{tabular}{|c|c|c|}
\hline $\begin{array}{c}\text { Stagnation } \\
4\end{array}$ & from 3 to 4 & $\begin{array}{c}\text { Production volume is limited, } \\
\text { financial indicators are falling } \\
\text { down }\end{array}$ \\
\hline 5 Decay & from 4 to 5 & $\begin{array}{c}\text { Production volumes are } \\
\text { limited, financial indicators are } \\
\text { falling down, deficit of } \\
\text { financial resources }\end{array}$ \\
\hline
\end{tabular}

The chosen model has shown results of the economic indicators in the process of organisation development. The realization changes in terms of LCS in various aspects: liquidity indicators; possibility to create positive cash flows (Ivashkovskaya, 2007); either for the undertaking itself or for separate business-processes (Pluzhnikov and Shikina, 2014); accounting of aggregates for business growth (Ivashkovskaya, 2007); dependence of investment activity of industrial undertaking (Smagin and Shikina, 2015).

The solution, that is necessary to find out a development stage, is crucial for developing investment policy of the pertinent strategy. Thus, the process for forming particular investment policy should take under consideration the level of business investment activity in correlation with its LCS.

\section{Estimation of LCS}

Qualitative estimation of LCS is a debatable issue that requires the usage of many theoretical approaches reflecting various market participants' interactions and characteristics. The problem is the lack of traditional theories forming markets and undertakings from the concept of the life-cycle. Contemporary theoretical models cannot choose correctly testing empirical data, so that available characteristics of industrial undertakings are used in order to do research of illustrating variables: organisation age (A), number of employees $(\mathrm{N})$, total assets (TA), total revenue (V), rate of assets increase (I) (Pluzhnikov and Shikina, 2015), Table 5 .

Table 5. Criteria of integrated index LCS.

\begin{tabular}{|c|c|c|c|c|c|c|}
\hline \# & Index name & $\begin{array}{c}\text { Mea } \\
\text { ning }\end{array}$ & Birth & Growth & Stabilization & $\begin{array}{c}\text { Stagn } \\
\text { ation }\end{array}$ \\
\hline 1 & $\begin{array}{c}\text { Index of } \\
\text { increments of } \\
\text { assets }\end{array}$ & $\mathrm{I}$ & $\geq 4,0$ & $2,0 \div 4,0$ & $1,0 \div 2,0$ & $<1,0$ \\
\hline 2 & $\begin{array}{c}\text { Number of } \\
\text { people (thous. } \\
\text { of people) }\end{array}$ & $\mathrm{N}$ & $\leq 0,1$ & $0,1 \div 1,0$ & $1,0 \div 10,0$ & reduce \\
\hline 3 & $\begin{array}{c}\text { Total Assets } \\
\text { (RUB bn) }\end{array}$ & $\mathrm{TA}$ & $\leq 0,02$ & $0,02 \div 1,5$ & $1,5 \div 15,0$ & reduce \\
\hline 4 & Sales (RUB bn) & $\mathrm{V}$ & $\leq 0,06$ & $0,06 \div 1,5$ & $1,5 \div 25,0$ & reduce \\
\hline 5 & $\begin{array}{c}\text { Enterprise age } \\
\text { (years) }\end{array}$ & $\mathrm{A}$ & $\leq 3,0$ & $3,0 \div 10,0$ & $10,0 \div 20,0$ & $20,0 \div 5$ \\
0,0
\end{tabular}

The next stage is formalization of interval frame for identification LCS according to the previous 
stated criteria (Table 5). One part of changing interval frame characteristics of LCS (Table 5) corresponds to Federal Law NO 209 - FZ 24.07.07. On developing small and medium scale entrepreneurship in the Russian Federation; with the Amendments and Additions of 22. 07. 08. № 556 On limits of revenue from sales (works, service) for each category of small and medium business. The other part is carried out by means of expert opinions.

Choosing of numerical expert score of criteria LCS is based on expert opinions of qualitative characteristics. We use the method of quantitative estimation of qualitative characteristics - numerical expert score of Kharrington scale. Due to the chosen method we get quantitative estimation $x_{i}$ of qualitative characteristics LCS with the usage of formulae $1-5$ :

$$
\begin{aligned}
& X_{1}=\left\{\begin{array}{lr}
0,20 & I \geq 4,0 \\
0,37 & 2,0 \leq I<4,0 \\
0,64 & 1,0 \leq \mathrm{I}<2,0 \\
0,80 & 0 \leq I<1,0 \\
1,00 & I<0
\end{array}\right. \\
& X_{2}=\left\{\begin{array}{cr}
0,20 & N \leq 0,1 \\
0,37 & 0,1<N<1,0 \\
0,64 & 1,0 \leq N<10,0 \\
0,80 & 10,0 \leq N<20,0 \\
1,00 & N_{t}<N_{t-1}
\end{array}\right. \\
& X_{3}=\left\{\begin{array}{c}
0,20 \\
0,37 \\
0,64 \\
0,80 \\
1,00
\end{array}\right. \\
& X_{4}=\left\{\begin{array}{l}
0,20 \\
0,37 \\
0,64 \\
0,80 \\
1,00
\end{array}\right. \\
& T A \leq 0,02 \\
& 0,02<T A<1,5 \\
& 1,5 \leq T A<15,0 \\
& 15,0 \leq T A<50,0 \\
& T A_{t}<T A_{t-1} \\
& V \leq 0,06 \\
& 0,06<V<1,5 \\
& 1,5 \leq V<25,0 \\
& V \geq 25,0 \\
& V_{t}<V_{t-1}
\end{aligned}
$$


activity. The rate of internal sources characterizes results of the operational activity. The financial activity is aimed at the balance of cash flows(inflow/outflow) connected with the realization of the investment and operational activities (Плужников et al., 2015).

The criterion of investment activity may estimate not only the dynamic vector of the investment activity but reflect risks of the investment activity in the realization of the stated development strategy. The organisation develops at various life-cycle stages so that different aspects and issues at diverse stages presuppose choosing several criteria to form investment policy.

\section{Graphical-analytic model to estimate investment policy}

It is extensively used in the economic theory as a tool for analyzing portfolio strategies to define reasonable diversification of undertaking activity. The most popular matrixes are following: BKG (The Boston Consulting Group), GE/McKinsey, ADL/LC (Osel and Wright, 1980), Shell/DPM, SPACE, Hofer/Shendel, Thompson, Strickland, strategic charts (BSC) (Lawrence, 1992) and etc. However, the data of the model doesn't open up opportunities to develop investment policy in accordance with its stated development strategy.

As a tool for developing investment policy in accordance with its stated development strategy the authors suggest graphical-analytic (diagnostic) model to form investment policy (Smaginand Shikina, 2012). The model $(4 \times 4)$ is based on qualitative characteristics reflecting criterion of investment activity Cia ( $\mathrm{Y}$-axis) and integrated criterion for estimating life-cycle stage $\mathrm{C}_{\mathrm{LC}}$ (X-axis) fig. 1).



Fig. 1. Diagnostic matrix of strategies (natural, specific development).

Possible trajectories of Cia index transition in the diagnostic model (fig.1) in the development process of the organisation at different life-cycle stages:

1 - trajectory of natural level of investment activity $\left(\mathrm{C}_{\mathrm{ia}}\right.$ $\left.=\mathrm{C}_{\text {nat }}\right)$ is characterized by eventual strategic changes in the process of realization reference strategies of natural development and ways of investment policy in accordance with business life-cycle. Trajectory 3 , fig. 1 ;

2 - trajectory of the specific level of investment activity $\left(\mathrm{C}_{\mathrm{ia}}>\mathrm{C}_{\text {nat }}\right)$ is characterized by intermittent nature of strategic changes in the process of redical business renovation If strategies "diversification" and correlated investment policies are conducted correctly, the trajectory of Cia is directed to the transmission of Cia from the stabilization or stagnation to the growth. Trajectory 1,2 . fig. 1.

Thus, investment policies directed to the realization of strategies which provide Cia rate to the rate that is similar to the natural level of investment activity are rational investment policies (Cnat) (Smagin and Shikina, 2012).

The diagnostic model based on the analysis and estimating vector of $\mathrm{Cia}$ defines the type of realized investment policy in accordance with the stated development strategy (Table 6). Defining the type of realized investment policy is based on the comparison of Cia to the rate of the natural level of investment policy (Cnat) with its correlated LCS.

Table 6. Correlation of the type of investment policy and Cia.

\begin{tabular}{|c|c|}
\hline $\begin{array}{c}\text { The type } \\
\text { of investment policy }\end{array}$ & $\begin{array}{c}\text { Criterion of intensity of } \\
\text { investment activity (Cia) }\end{array}$ \\
\hline Concervative & $\mathrm{K}_{\mathrm{UA}}<$ Cnat, (passive) \\
\hline Moderate & $\mathrm{K}_{\mathrm{UA}}=$ Cnat (moderate) \\
\hline Aggressive & $\mathrm{K}_{\mathrm{UA}}>$ Cnat (active, high) \\
\hline
\end{tabular}

On the basis of research results on data from the table 7 (Smaginand Shikina, 2012), it can be possible to mark LCS and $\mathrm{Cia}$ rates which are corresponded to its natural level of investment activity (Cnat).

Table 7. Rate of Cnat on LCS.

\begin{tabular}{|c|c|c|}
\hline № & The type & Rate of Cnat \\
\hline 1 & $\begin{array}{c}\text { The stage birth - area of strategies } \\
\text { "forming new business" }\end{array}$ & Cia $>4,0$ \\
\hline 2 & $\begin{array}{c}\text { The stage growth - area of } \\
\text { strategies "growth" }\end{array}$ & $2,0<\mathrm{Cia}<4,0$ \\
\hline 3 & $\begin{array}{c}\text { The stage stabilization - area of } \\
\text { strategies "cost saving" }\end{array}$ & $1,0 \quad$ Cia $\quad 2,0$ \\
\hline 4 & $\begin{array}{c}\text { The stage "stagnation" - area of } \\
\text { strategies "liquidation" }\end{array}$ & Cia $\quad 1,0$ \\
\hline
\end{tabular}

Range of Cia rates for different branches in accordance with industry specialization may vary but functional dependence Cnat on LCS has a unique character. fig. 2, table 7.

Cia



Fig. 2. Area of natural business development. 
Diagnostic matrix includes 4 areas introduced in the table 8 .

Table 8. Areas of choosing investment policies.

\begin{tabular}{|c|c|}
\hline The area & Concept \\
\hline $\begin{array}{l}\text { Mainstream } \\
\text { business } \\
\text { development } \\
\text { (natural) }\end{array}$ & $\begin{array}{l}\text { Corresponds to sequent life-cycle } \\
\text { stages of business development ( } \\
\text { matrix cells or positions } 1 ; 6 ; 11 ; \\
\text { 16, fig. 2). On the diagonal rates } \\
\text { of investment activity (Cia=Cnat, } \\
\text { table } 7 \text { ) for corresponding life- } \\
\text { cycle stage (fig. 2); }\end{array}$ \\
\hline $\begin{array}{c}\text { Eventual } \\
\text { development } \\
\text { (higher risk) }\end{array}$ & $\begin{array}{l}\text { The rate of coefficient of } \\
\text { investment activity (Cia }>\text { Cnat, } \\
\text { table } 7 \text { ). In result of realizing } \\
\text { development strategy another } \\
\text { capital raising leads to higher } \\
\text { financing business and risk } \\
\text { growth (matrix cells or positions } \\
2 ; 3 ; 4 ; 7 ; 8 ; 12 \text { fig. } 3 \text { ). } \\
\text { Investment policies should be } \\
\text { aimed at putting Cia to its natural } \\
\text { level (positions } 1 ; 6 ; 11 ; 16 \text {, fig. } 3 \\
\text { a, b, c); }\end{array}$ \\
\hline $\begin{array}{l}\text { Eventual } \\
\text { development } \\
\text { (low risk) }\end{array}$ & $\begin{array}{l}\text { In the process of natural } \\
\text { development the organisation } \\
\text { needs to cary out more active } \\
\text { policy and putting Cia = Cnat } \\
\text { (fig. } 4, a, b, c) \text {. If an undertaking } \\
\text { has no opportunities to raise } \\
\text { necessary volume of investments } \\
\text { to provide business development, } \\
\text { it should liquidate its business; }\end{array}$ \\
\hline $\begin{array}{c}\text { Cash } \\
\text { generation }\end{array}$ & $\begin{array}{c}\text { The rate of Cia is lower } 1.0 \text { that is } \\
\text { lower natural level Cia }<\text { Cnat } \\
\text { (matrix cell or positions } 15 \text {, fig. } 4 \\
\text { c). }\end{array}$ \\
\hline
\end{tabular}

To each area of forming investment policy belong a particular rate of assets change and amount of investments. Corresponding ways of investment policy for each matrix position obtain the following economic meaning:

- Position 1. Forming new business (fig. 2) - at this stage internal investment sources $(\mathrm{NP}+\mathrm{Am})$ are very small because of inability to generate necessary volume of cash flow so that relative Cia rate of investment activity is large ( $\mathrm{Cia}>4,0)$;

- Position 6. Concentrated integrated growth (fig. 2) characterized by sales growth that is described by significant increase assets. So that external development sources are not necessary. It is reflected in the relative coefficient reduction $(2,0 \leq$ Cnat $<4,0)$; - Position 11. Cost saving (fig. 2). Production volumes and increase of assets are slow so that it leads to the further coefficient decrease $(1,0 \leq$ Cnat $\leq 2,0)$. According to the further natural development this position is unpromising because it leads to the position 16 (fig. 2). To renovate business a new type of development is necessary that is realization strategies "specific development". Investment policy is directed to putting $\mathrm{Cia}$ at the growth stage (trajectory 1 fig. 1);
- Position 16. Liquidation (fig. 2). The assets growth decreases because the production volume falls. Business stagnates, the undertaking business results in "death" without radical changes of natural development strategies (trajectory 3, fig. 1; 2) (Cnat < $1,0)$. For prolongation of life undertakings need radical business renovation and realization of specific development strategy that is putting Cia at the growth stage (trajectory 2, fig. 1).

Positions of the diagnostic model (positions 1; 6; 11 ; 16) points out the area of higher investment activity (fig. 4). Corresponding ways of investment policy for each matrix position obtain the following economic meaning:

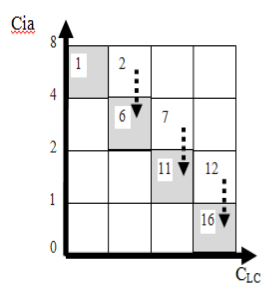

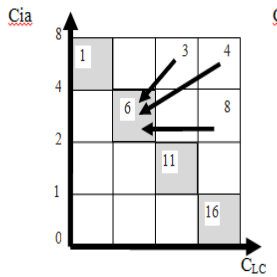

b)

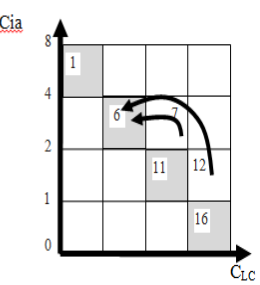

Fig. 3. Area of extra encouraging financial sources of business development.

Corresponding ways of investment policy for each matrix position obtain the following economic meaning:

- Positions 2, 7, 12. The rate of the coefficient of investment activity $\mathrm{Cia}>\mathrm{Cnat}$ that is it's higher than natural level. This situation can be considered as realization of concentrated (integrated) growth and/or diversification. Assets grow due to encouraging extra financial sources that lead to overaged risk growth. In the frame of natural business development (fig. 3a) the business has overaged assets growth and realization of investment policy, correlated cost saving strategy. It may lead coefficient of investment activity to its natural $\mathrm{Cia}=\mathrm{Cnat}$. Or it can be considered as diversification strategy. In this case the rate of $\mathrm{Cia}>\mathrm{Cnat}$ is higher than the natural level and aimed at the development of new business types.

- Positions 3, 4, 8 should not be considered from the position of natural business development. As a rule they are coefficients of realizing diversification strategies (fig. 3 b).

Positions of the diagnostic model are placed lower than the diagonal (of natural level) and point out the area of low investment activity of a company (fig. 4).

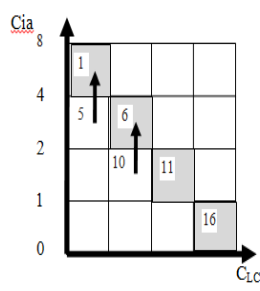





Fig. 4. Insufficient financing of business development. 
Corresponded ways of investment policy for each position of the matrix (fig. $4 a, 4 b, 4 c$ ) obtains the following economic sense:

- The level of investment activity is not enough for the positions 5 and 10. The investment policy should be aimed at $\mathrm{Cia}$ growth and putting $\mathrm{Cia}$ to the natural level (Cnat) so that to natural business development (positions 1; 6; fig. 4a)

- Positions 9, 13, 14. The rate of investment activity is critical, the undertaking can be estimated as a potential bankrupt (fig. 4b, 4c).

- The position 15 of cash generation that is $\mathrm{Cia}<1,0$. Business stagnates. The undertaking has 2 options for development. In the frame of natural development it's necessary to carry out investment policy and correlated cost saving strategies. As a result, Cia transmits from the position 15 to the position 16 (fig. 4c). In the frame of specific development the investment policy is directed to diversification of activity and putting Cia from the position 15 to the position 11 (fig. 4c).

\section{Analysis of investment policy}

For approbation of the given method the analysis of investment policy of 2 leading pipe and tube production companies in the Russian Federation should be conducted. The research is conducted at several stages. At the first stage the analysis and estimate of the lifecycle stage is carried out.

Undertakings OAO Sinarsky Pipe Manufacturer (OAO SinPM) and OAO Vyksunsky Metallurgical Plant (OAO VMZ) are leading plants in the branch. The main financial criteria characterize their stable statement. The structure of real assets is relatively stable during the whole analyzing period that is pertinent to developmental manufacturing industries with the static technology when the business is satisfied with its position. The life-cycle imitates production life-cycles and applied technologies life-cycles that are characterized for the correlated industrial branches. According to the experience the length of the organisation life-cycle for different types of economic activities may vary but the character of the trajectory will be the same (Shirokova 2006).

According to the data from the financial statements of OAO "SinPM" and OAO "VMZ" on 01.01.2014 we can calculate the quantitative estimate $\mathrm{C}_{\mathrm{LC}}$. The calculation results are introduced in the table 9.

Table 9. Results of estimate $\mathrm{C}_{\mathrm{LC}} \mathrm{OAO}$ "SinPM", OAO "VMZ" on 01.01.2014.

\begin{tabular}{|c|c|c|c|c|c|}
\hline \multirow[b]{2}{*}{ \# } & \multirow[b]{2}{*}{$\begin{array}{l}\text { The } \\
\text { crite } \\
\text { rion }\end{array}$} & \multicolumn{2}{|c|}{$\begin{array}{c}\text { The company OAO } \\
\text { "SinPM" }\end{array}$} & \multicolumn{2}{|c|}{$\begin{array}{l}\text { The company } \\
\text { OAO "VMZ" }\end{array}$} \\
\hline & & $\begin{array}{c}\text { The } \\
\text { virtual } \\
\text { meaning }\end{array}$ & $\begin{array}{c}\text { Estimate } \\
\text { on } \\
\text { Kharring } \\
\text { ton scale }\end{array}$ & $\begin{array}{c}\text { The } \\
\text { virtual } \\
\text { meaning }\end{array}$ & $\begin{array}{c}\text { Esti } \\
\text { mate } \\
\text { on } \\
\text { Khar } \\
\text { rington } \\
\text { scale }\end{array}$ \\
\hline 1 & $\begin{array}{c}\text { Index of } \\
\text { increme } \\
\text { nts of } \\
\text { assets }\end{array}$ & 1.10 & 0.64 & 1.05 & 0.64 \\
\hline
\end{tabular}

\begin{tabular}{|c|c|c|c|c|c|}
\hline & $\begin{array}{c}\text { Number } \\
\text { of } \\
\text { people } \\
\text { thous. } \\
\text { of } \\
\text { people) }\end{array}$ & 10000 & 0.80 & 12000 & 0.80 \\
\hline $\begin{array}{c}\text { Total } \\
\text { Assets } \\
\text { (RUB } \\
\text { bn) }\end{array}$ & 21000 & 0.80 & 120000 & 0.80 \\
\hline $\begin{array}{c}\text { Sales } \\
\text { (RUB } \\
\text { bn) }\end{array}$ & 23000 & 0.64 & 85000 & 0.80 \\
\hline 5 & $\begin{array}{c}\text { Enterpri } \\
\text { se age } \\
\text { (years) }\end{array}$ & $\begin{array}{c}\text { more } \\
\text { than } 50\end{array}$ & 1.00 & $\begin{array}{c}\text { more } \\
\text { than } 50\end{array}$ & 1.00 \\
\hline \multicolumn{2}{|c|}{ Total } & 3,88 & 4,04 \\
\hline
\end{tabular}

Integrated criterion is derivative reflecting the correlation of all estimate criteria LCS. Expert estimate LCS composed 3,88 for OAO "SinPM" and 4,04 for OAO "VMZ" that are corresponded to LCS stagnation. At the stagnation the basic tendency is demand decrease, reduction of competitors and narrowing of product proposal.

At the second stage the criterion calculation of investment activity is carried out using formula 7 . The calculation results are introduced in the table 10 . Graphical reflection of $\mathrm{Cia}$ of the company OAO "SinPM" and OAO "VMZ" are introduced in the fig. 5 .

Table 10. Cia dynamics of investment activity.

\begin{tabular}{|c|c|c|c|c|c|c|c|}
\hline \multirow{2}{*}{$\begin{array}{c}\text { The } \\
\text { company }\end{array}$} & \multicolumn{6}{|c|}{ Period } & \multirow{2}{*}{$\begin{array}{c}\text { Average } \\
\text { value } \\
\text { Cia }\end{array}$} \\
\hline & 2008 & 2009 & 2010 & 2011 & 2012 & 2013 & \\
\hline "SinPM" & 0.64 & -5.91 & -0.08 & -0.11 & -0.23 & 0.85 & 0.31 \\
\hline "VMZ" & 0.36 & 1.00 & 2.02 & 0.14 & 0.79 & 0.14 & 0.16 \\
\hline
\end{tabular}

In the period from 2006 to 2014 the Cia vector is placed in the area of the natural level of investment activity characterizing its stability and moderation of investment policy in the frame of natural development strategy (see fig. 5).

At the third stage the analysis and estimate of investment policy according to the $\mathrm{Cia}$ vector are conducted. In the period from 2006 to 2014 the Cia vector of the company OAO "SinPM" is placed lower that the natural level of investment activity $\mathrm{C}_{\mathrm{NAT}}$, that corresponds to the passive investment policy (see fig. 5, table 10).

In the frame of realizing cost saving the company OAO "SinPM" needs actions on decrease of expanses to the income amounts and restructuring indebtedness. These actions will balance the structure of real assets and their sources. The realization of investment policy may lead the Cia to its natural rate $\mathrm{C}_{\mathrm{NAT}}$ and come over the position 16 "stagnation"(fig. 2).

In the period from 2008 to 2013 the Cia vector of the company OAO "VMZ" is placed higher than the natural level of investment activity $\mathrm{C}_{\mathrm{NAT}}$. According to the rate it corresponds to moderate investment 
policy (see fig. 5, table 10) in the frame of diversification strategy.

To protect the position at the stagnation stage in the frame of natural development realizing cost saving strategy will lead to the recovery of business activity.

\section{Discussion}

Comparison of estimate results of the investment policy based on the analyzing Cia vector (analytical model) of the industrial companies introduced on the fig. 5. and financial analysts' opinions introduced in the table 11 may prove the authenticity of the given method.

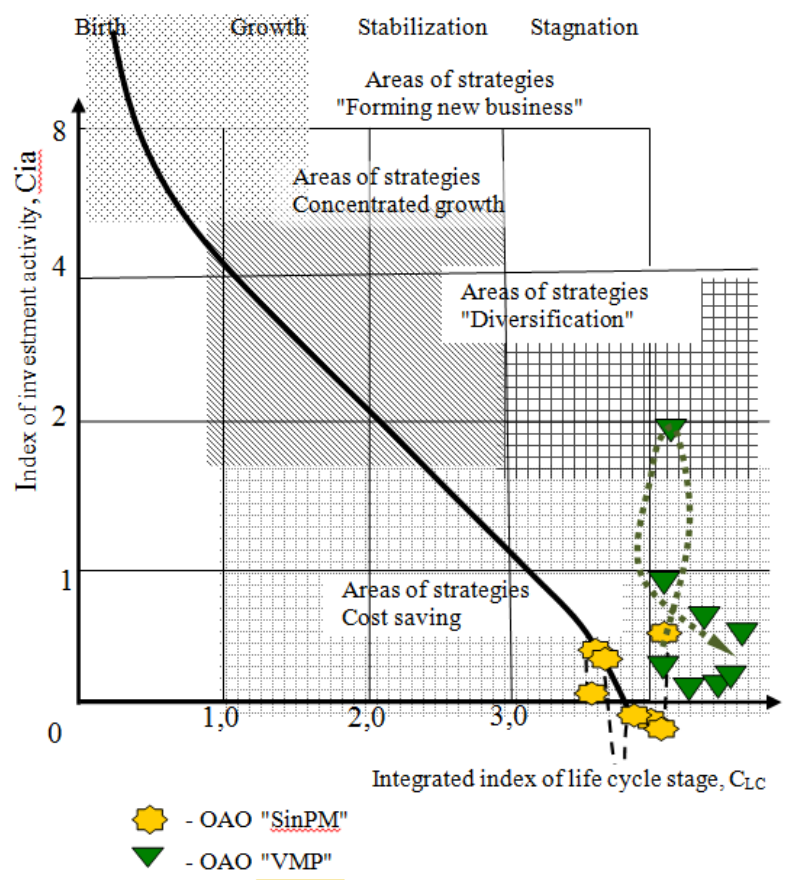

Fig. 5. The Cia vector of the companies OAO "SinPM" and OAO "VMZ" from 2008 to 2013.

Table 11. Comparison of estimate results of investment policy.

\begin{tabular}{|c|c|c|}
\hline $\begin{array}{c}\text { The } \\
\text { company }\end{array}$ & $\begin{array}{c}\text { External estimate } \\
\text { on financial } \\
\text { analysts data }\end{array}$ & $\begin{array}{c}\text { Estimate base on } \\
\text { the analytical } \\
\text { model } \\
\left(\mathbf{C i a}-\mathbf{C}_{\mathbf{L C}}\right)\end{array}$ \\
\hline "SinPM" & $\begin{array}{c}\text { passive investment } \\
\text { policy }\end{array}$ & $\begin{array}{c}\text { passive investment } \\
\text { policy }\end{array}$ \\
\hline "VMZ" & $\begin{array}{c}\text { moderate } \\
\text { investment policy }\end{array}$ & $\begin{array}{c}\text { moderate } \\
\text { investment policy }\end{array}$ \\
\hline
\end{tabular}

The conclusions are proved by analysts financial review introduced on financial web-sites of the company OAO "VMZ" (Fundamental analytics, OAO Vyksunsky Metallurgic Plant) http://www.omk.ru/vmz/smi/5688/?back url list=/vm z) and financial analysts opinions OAO "SinPM" (Finanalytics, OAO "Synarsky Pipe Manufacturer" https://sintz.tmk-group.ru).

\section{Conclusion}

While the research and approbation of the graphical-analytic model to form investment policy in accordance with the stated strategy and its development we can conclude that

- graphical-analytic model may diagnose on the Cia vector the type of realizing investment policy and its correlation to the stated development strategy;

- graphical-analytic model to form investment policy may realize control, adjustment and diagnostics of intensity of investment activity;

- quantitative estimate of the model position may forecast the results of realizing investment policy and expect either entrepreneurial or financial risks.

Calculation of Cia and LCS is conducted in accordance with the financial statement that complicates the research of impact on Cia realizing investment policy in separate business processes.

The work was supported by Act 211 Government of the Russian Federation, contract № 02.A03.21.0011.

\section{References}

1. S.O. Ashirov, K.V. Rzayev, Estimate investment activity of industrial undertakings (GUU, Moscow, 2000)

2. I.A. Blank, Investment policy of organisation: eight main stages. http://www.elitarium.ru/2012/11/21/investicionna ja_politika_predprijatija.html

3. A. Damodaran, Investment valuation: Tools and techniques for the valuation of any assets (Alpina Business books, Moscow, 2006)

4. D.A. Yendovitsky, A.N. Isayenko, Financial organisation reserves: analysis and control (KNORUS, Moscow, 2007)

5. D.A. Yendovitsky, Analysis and estimating effective business investment policy: Methodology and methods (Publishing house of Voronezh state university, Voronezh, 1998)

6. F. Glazl, B. Livekhud, Dynamic development of entrepreneurship: How pioneer-entreprises and the bureaucracy can become effective (Dukhovnoe poznanie, Kaluga, 2000)

7. L.A. Gordon, R.J. Iyengar, Journal of Accounting and Public Policy, 15, 305-325 (1996)

8. L.E. Greiner, News St. Petersburg . Univ . Ser. Management, 4, 76-94 (2002)

9. I.V. Ivashkovskaya, D.O. Yangel, Corporate Finance, 4, 97-110 (2007)

10. E.I. Kushelevich, S.R. Filonovich, Management: $X X$ century - XXI century (Ekonomist, Moscow, 2004) 
11. D.L. Lester, J.A. Parnell, S. Carraher, The International Journal of Organizational Analysis, 11, 4, 339-354 (2003)

12. Lawrence S. Maisel, Journal of Cost Management, Summer (1992)

13. D. Miller, P.A. Friesen, Management Science, 30, 11161-1180 (1984)

14. E.B. Morgunov, Organizational behaviour: tutorial (Izd-vo MGUPI, Moscow, 2006)

15. Roger R. Osel, V.L. Wright Robert, Allocating resources: How to Do It in Multi-Industry Corporations. Handbook of Business Problem Solving (McGrow-Hill, New York, 1980)

16. V.G. Pluzhnikov, S.A. Shikina, Management of the economic system: the Electronic Journal of Research, 10 (2014). http://uecs.ru/uecs70702014/item/3087-2014-10-18-08-24-48.

17. V.G. Pluzhnikov, V.N. Smagin, S.A. Shikina, Economic analysis: research and practice, 2(401), 2-10 (2015)

18. V.G. Pluzhnikov, S.A. Shikina, Research and practice analytical journal: Economic analysis theory and practice, 44(443), 53-64 (2015)
19. V.N. Smagin, S.A. Shikina, Vestnik South Ural State University. Series: Economic and management, 9(268), 88-90 (2012)

20. G.V. Shirokova, O.Yu. Serov, Vestnik SPbSU, 8, 1, 3-27 (2006)

21. G.V. Shirokova, Editorial commission of Vestnik SPbGU, 8, 2, 25-42 (2006)

22. G.V. Shirokova, Russian Management Journal, 5, 3, 85-90 (2007)

23. D.A. Tikhonov, Modeling funding impact on investment activity (St. Petersburg, 2003)

24. M.V. Charayeva, Financial management, 2, 97104 (2010)

25. K. Walsh, Key indicators of management: How to analyze, compare and control to regulate the data that defines the value of the company (Case, Moscow, 2000)

26. D. Young, European Management Journal, 15, 4, 335-344 (2006) 